\title{
Removal of Sulfur from Myanmar Coals by Using Desulfurization Method
}

\author{
Mar Mar Thi \\ Department of Fuel and \\ Propellant Engineering \\ Myanmar Aerospace \\ Engineering University \\ Meikhtila, Myanmar
}

\author{
Ye Lin Tun \\ Department of Chemical \\ Engineerig \\ Defence Services \\ Technological Academy \\ Pyin Oo Lwin, Myanmar
}

\author{
Yan Naing Kyaw \\ Department of Chemical \\ Engineerig \\ Defence Services \\ Technological Academy \\ Pyin Oo Lwin, Myanmar
}

\begin{abstract}
The desulfurization of coal is a pre-processing in order to achieve clean fuel and reduce environmental impacts. In this research, the different coals from Myanmar were collected and each of them was grind and separated in various sizes. The obtained different mesh sizes of Myanmar Coals were leached with $\mathrm{H}_{2} \mathrm{O}_{2} / \mathrm{H}_{2} \mathrm{SO}_{4}$ at different temperatures $\left(65^{\circ} \mathrm{C}, 75^{\circ} \mathrm{C}, 85^{\circ} \mathrm{C}\right.$ and $\left.95^{\circ} \mathrm{C}\right)$ and different leaching time (10 min, $20 \mathrm{~min}, 30 \mathrm{~min}, 40 \mathrm{~min}$ and $50 \mathrm{~min}$ ). The samples after removing sulfur were tested how much sulfur content decrease. In this processes, effects of the leaching temperature, agitation time and particle size on the removal of different forms of sulphur from Myanmar coals were very significant. The optimum values of leaching temperature, agitation time and particle size of coal were obtained for this processes. The calorific values of coals which have leached were compared with that of Myanmar original coals. It can find how the leached coals effect to calorific values of it in burning.

Keywords: desulfurization, Myanma coal, leaching temperature, agitation time, calorific values
\end{abstract}

\section{INTRODUCTION}

Coal is the most important nonrenewable energy source of fossil origin. It is also the most common fuel in thermal power plants. In recent years, with the rising prices of crude oil and natural gas and shortage of oil and gas resources, worldwide energy industries have been focusing on accelerating the development of coal chemical industry. The coal chemical industry can make a significant contribution in the sustainable development of some countries' energy resources in the next twenty years. It will also reduce dependency on oil and gas as energy sources.

Coal usually contains significant quantities (normally more than $10 \%$ ) of different impurities such as sulfur, silicates, carbonates, etc. Harmful effects on agricultural products, corrosion of metal structures and respiratory problems of humans and animals are undesirable effects of sulfur and its compounds in coal. Therefore, it is essential to reduce sulfur and mineral matter from coal.

Coal is also one of the main sources of energy on the world. Economic growth and industrialization in developing countries are leaching to a rapid increase in the demand for energy which is inexpensive and readily available, for electric power and process heat. When coal is burned generally $90 \%$ or more of the sulfur present in it is emitted into the atmosphere as sulfur oxides (mainly $\mathrm{SO}_{2}$ ), if no desulfurization methods are used before, during and after combustion. It is well-known that $\mathrm{SO}_{2}$ emissions are considered one of the main causes of acid rain, which leads to the acidification of soils, forests, and surface of water. The growth in coal-fired capacity has, therefore, led to increasing concern about environmental issues, such as increased emissions of $\mathrm{SO}_{2}$, nitrogen oxides $\left(\mathrm{NO}_{\mathrm{x}}\right)$, trace elements, and particulates, although most effort has been directed towards the control of $\mathrm{SO}_{2}$ emissions.

The reduction of $\mathrm{SO}_{2}$ emissions in the use of coal, in particular from coal combustion, can be done by the following option: The use of coal having low sulfur content, pre- treatment of coal for sulfur removal, sulfur capture during combustion and post-combustion treatment of flue gas.

Removal of sulfur techniques are classified as physical, chemical, thermal and biological. Such techniques are extensively applied for coal desulfurization prior to combustion. Most of research work on coal desulfurization has been focused on pyritic sulfur removal. Organic sulfur is more difficult to be removed by conventional processes since it is firmly bonded to organic units.

Coals are founded throughout the many places in Myanmar. They are got mainly in the upper parts of Mandalay Division, in the northern parts of Sagaing Division, and Shan State. They are found in a few places of Bago Division, Naypyitaw Division, Tanintharyi Division and eastern parts of Shan State.

Most of coals in Myanmar are only Sub-bituminous and Lignite coals. Few of Anthracite coal can be found in Kalaw region. Myanmar produces limited amounts of subbituminous coal and lignite from small-scale surface mines located primarily in the northern part of the country. The usage of coal in Myanmar is limited to domestic cement, steel and other industry requirements.

\section{EXPERIMENTAL PROCEDURES 2.1 Preparation of Raw Coals}

The solid types of various raw coals from Namma (Sagaing Division), Kyaukmel (Shan State ) and Pinlebu (Sagaing Division) were analyzed to obtain the required size of raw materials by grinding machine and screening machine. The raw coal and screen analysis of various coals were shown in (Figure 1 and Figure 2).

There are five kinds of coal obtaining by screening machine. They are as follows: 
(1) Size No. (1), over 2000 micrometer

(2) Size No. (2), between 2000 micrometer and 1000 micrometer

(3) Size No. (3), between 1000 micrometer and 500 micrometer

(4) Size No. (4), between 500 micrometer and 125 micrometer

(5) Size No. (5), under 125 micrometer

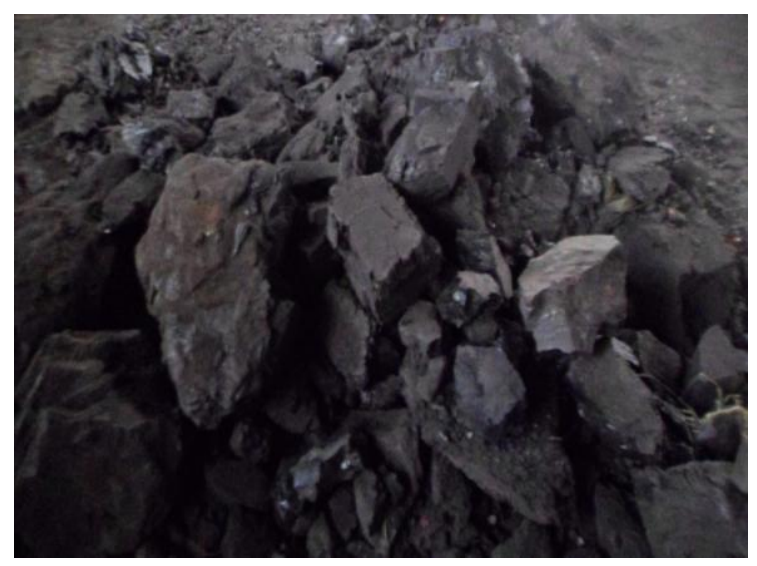

Figure. 1 Myanmar raw coals

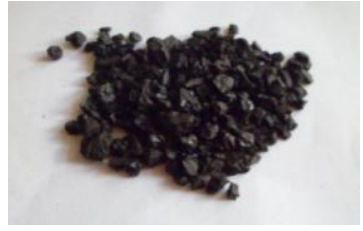

(a)

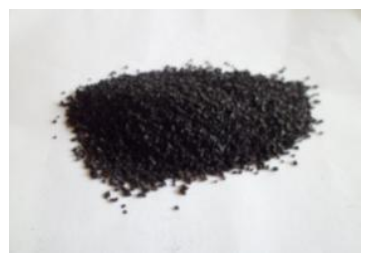

(c)

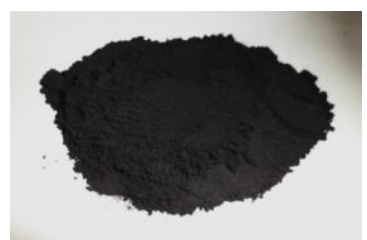

(e)

Figure. 1 Screen analysis of various coals

(a) Coal Sample, Size No.1 (over $2000 \mu \mathrm{m}$ )

(b) Coal Sample, Size No.2 (between $2000 \mu \mathrm{m}$ and $1000 \mu \mathrm{m}$ )

(c) Coal Sample, Size No.3 (between $1000 \mu \mathrm{m}$ and $500 \mu \mathrm{m}$ )

(d) Coal Sample, Size No.4 (between $500 \mu \mathrm{m}$ and $125 \mu \mathrm{m}$ )

(e) Coal Sample, Size No.5 (under $125 \mu \mathrm{m}$ )

\subsection{Characterization of Raw Coals}

The characterizations of raw coals were determined to know the properties of the origin condition of raw.
The moisture content, ash content, volatile matter content, fixed carbon content, calorific values and chemical compositions of various raw coals from Namma, Kyaukmel and Pinlebu were determined and this results were shown in (Table 1).

Table 1. Characterization of different Myanmar coals

\begin{tabular}{|c|c|c|c|c|}
\hline $\begin{array}{l}\text { Sr. } \\
\text { No }\end{array}$ & $\begin{array}{l}\text { Composi- } \\
\text { tions }\end{array}$ & $\begin{array}{c}\text { Namma } \\
\text { Coal }\end{array}$ & $\begin{array}{c}\text { Kyaukmel } \\
\text { Coal }\end{array}$ & $\begin{array}{c}\text { Pinlelbu } \\
\text { Coal }\end{array}$ \\
\hline 1. & $\begin{array}{c}\text { Moisture } \\
\text { content }(\%)\end{array}$ & 12.90 & 10.06 & 4.213 \\
\hline 2. & $\begin{array}{c}\text { Ash } \\
\text { content }(\%)\end{array}$ & 11.31 & 9.49 & 54.86 \\
\hline 3. & $\begin{array}{c}\text { Volatile } \\
\text { Matter } \\
\text { (wet) }(\%)\end{array}$ & 39.55 & 52.37 & 8.607 \\
\hline 4. & $\begin{array}{c}\text { Fixed } \\
\text { Carbon (\%) }\end{array}$ & 36.24 & 28.08 & 32.32 \\
\hline 5. & $\begin{array}{l}\text { Hydrogen } \\
\text { content (\%) }\end{array}$ & 4.160575 & 4.44485 & 1.926813 \\
\hline 6. & $\begin{array}{c}\text { Nitrogen } \\
\text { content }(\%)\end{array}$ & 1.11698 & 1.061 & 0.75617 \\
\hline 7. & $\begin{array}{c}\text { Carbon } \\
\text { content }(\%)\end{array}$ & 59.55672 & 62.18 & 33.43611 \\
\hline 8. & $\begin{array}{c}\text { Oxygen } \\
\text { content }(\%)\end{array}$ & 8.30284 & 10.26863 & 1.967724 \\
\hline 9. & $\begin{array}{c}\text { Sulfur } \\
\text { content }(\%)\end{array}$ & 0.531 & 0.581 & 0.807 \\
\hline 10. & $\begin{array}{c}\text { Others } \\
\text { content }(\%)\end{array}$ & 2.11989 & 1.91452 & 2.03318 \\
\hline 11. & $\begin{array}{l}\text { Calorific } \\
\text { Value } \\
\text { (Btu/lb) }\end{array}$ & 10393.25 & 10810.83 & 5685.33 \\
\hline
\end{tabular}

\subsection{Preparation of Solvent Solution}

For chemical leaching method, 98\% sulfuric acid, 97\% hydrogen peroxide and distilled water were mainly used for removal of any form of sulfur in coal. In this process, to obtain $0.08 \mathrm{~N}$ solution the required amount of concentrated sulfuric acid was weighed and mixed with distilled water. The temperature of the dilute solution was increased in the mixing time, for exothermic reaction. The increased temperature was gradually decreased to the normal condition with increasing time. 97\% hydrogen peroxide was also weighed and added to the dilute solution in this normal condition.

\subsection{Removal of Sulfur by Chemical Leaching Method}

\subsubsection{Preparation of Coal Sample}

In the method of sulfur removal from coal, the required amount of Namma coal was weighed and put into a beaker. And then, the prepared solution was added to the beaker, drop by drop by using a burette. When the solution was added, the reaction temperature was increased and the foam was formed very rapidly. After finishing the mixing, the temperature was decreased to the normal stage slowly. The preparation of coal sample was shown in (Table 2). 
Table 2. Raw materials for sulfur removing process

\subsubsection{Heating and Agitation}

\begin{tabular}{|c|c|c|}
\hline Raw Materials & Weight, g & $\begin{array}{c}\text { Weight } \\
\text { Percentage, \% }\end{array}$ \\
\hline $\mathrm{Coal}$ & 20 & 14.02 \\
\hline $\mathrm{H}_{2} \mathrm{SO}_{4}$ & 73.6 & 51.61 \\
\hline $\mathrm{H}_{2} \mathrm{O}_{2}$ & 29 & 20.33 \\
\hline $\mathrm{H}_{2} \mathrm{O}$ & 20 & 14.02 \\
\hline Total & 142.6 & 100 \\
\hline
\end{tabular}

After finishing the preparing of coal sample, the beaker was put onto the heater and agitated with stirrer about $200 \mathrm{rpm}$ and the agitation temperature was $65{ }^{\circ} \mathrm{C}$ for one hour. The reaction was completed in one hour agitation time. To determine the optimum temperature, the similar process was done in various agitation temperatures $\left(75^{\circ} \mathrm{C}, 85^{\circ} \mathrm{C}\right.$ and 95 ${ }^{\circ} \mathrm{C}$, respectively).

\subsubsection{Washing and Filtration}

After finishing heating and agitation, the sample coals were washed with distilled water. Over 6 liters of distilled water was used for washing process. In washing step, it is needed to wash again and again until the spent water maintains about $\mathrm{pH}$ 7. It is very important for the results in the determination of sulfur content may be false because of sulfuric acid. After washing the sample, it is filtrated with filter paper

\subsubsection{Drying}

After finishing the above steps, the samples are needed to remove their moisture content. Therefore, the samples were dried at $120^{\circ} \mathrm{C}$ in oven for 12 hours to evaporate the moisture. After cooling and drying, the desulfurized coal was obtained. It is shown in (Figure 2.)

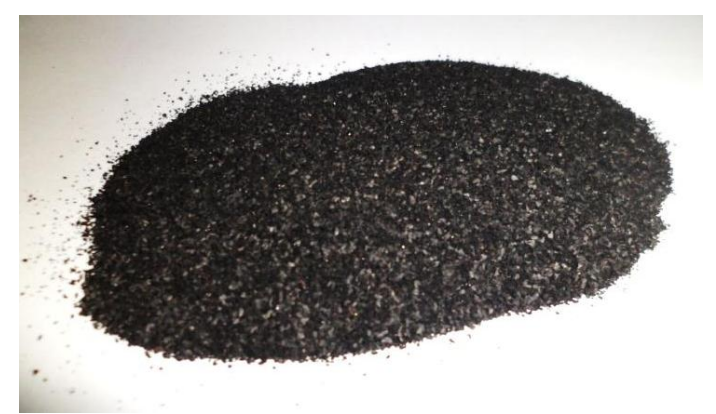

Figure. 2 Myanmar desulfurized coal

In the desulfurization process, various reactant temperatures, various mesh sizes of sample and various reaction times were used to determine the optimum condition.

The desulfurization of coals from Kyaukme and Pinlebu were also made as above procedure.

\subsubsection{Methodology for Sulfur Removing Process}

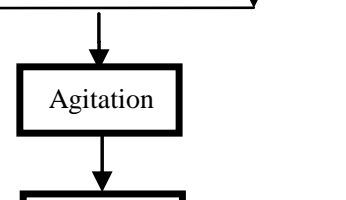

Heating

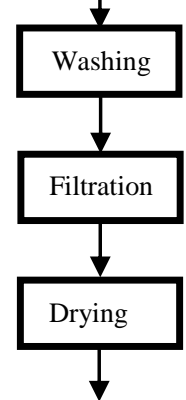

Desulfurized coal

Figure. 3 Block diagram of sulfur removal of coal by solvent leaching method

\section{RESULTS AND DISCUSSION}

\subsection{Determination of Sulfur Content from}

\section{Different Desulfurized Coals}

The total sulfur contents in the different raw coals from Namma, Kyaukmel and Pinlelbu were determined by the high temperature combustion method, according to ISO- R 351.

The optimum reactant temperature, optimum size of samples and optimum reaction time were obtained by this method.

The optimum conditions for desulfurization of Kyaukmel coal and Pinlelbu coal were obtained by the similar method.

The theoretical percentage of completion of desulfurization of different coals is shown in (Table 3).

Table 3. Theoretical percentage of completion of desulfurization of different Myanmar coals

\begin{tabular}{|c|c|c|c|}
\hline $\begin{array}{c}\text { Raw } \\
\text { Material }\end{array}$ & $\begin{array}{c}\text { Sulfur } \\
\text { percent in } \\
\text { initial } \\
\text { coal }\end{array}$ & $\begin{array}{c}\text { Sulfur } \\
\text { percent in } \\
\text { final coal }\end{array}$ & $\begin{array}{c}\text { Percentage of } \\
\text { completion of } \\
\text { desulfurization }\end{array}$ \\
\hline $\begin{array}{c}\text { Namma } \\
\text { Coal }\end{array}$ & $0.531 \%$ & $0.1535 \%$ & $71.09 \%$ \\
\hline $\begin{array}{c}\text { Kyaukmel } \\
\text { Coal }\end{array}$ & $0.581 \%$ & $0.1595 \%$ & $72.55 \%$ \\
\hline $\begin{array}{c}\text { Pinlelbu } \\
\text { Coal }\end{array}$ & $0.807 \%$ & $0.1585 \%$ & $80.36 \%$ \\
\hline
\end{tabular}

\subsection{Characterization of Different Myanmar Coals}

(Table 4) show the compositions and calorific values of different Myanmar coals.

Table 4. Compositions and calorific values of different Myanmar coals

According to the (Table 1), the compositions of various coals were different with different places. The moisture content and 
ash content of Namma coal were greater than the two others. The presence of carbon content in Kyaukmel was the greatest in all coals and the calorific value of that coal was the highest, therefore the rate of combustion of that coal was the best condition in all coals. Pinlelbu coal, more present of sulfur content and less percent of carbon content were found in this result.

\begin{tabular}{|c|c|c|c|c|}
\hline $\begin{array}{l}\text { Sr. } \\
\text { No }\end{array}$ & $\begin{array}{c}\text { Composition } \\
\text { S }\end{array}$ & $\begin{array}{c}\text { Namma } \\
\text { Coal }\end{array}$ & $\begin{array}{c}\text { Kyaukmel } \\
\text { Coal }\end{array}$ & $\begin{array}{c}\text { Pinlelbu } \\
\text { Coal }\end{array}$ \\
\hline 1. & $\begin{array}{l}\text { Moisture } \\
\text { content }(\%)\end{array}$ & 12.90 & 10.06 & 4.213 \\
\hline 2. & $\begin{array}{l}\text { Ash content } \\
(\%)\end{array}$ & 11.31 & 9.49 & 54.86 \\
\hline 3. & $\begin{array}{l}\text { Volatile } \\
\text { Matter (wet) } \\
(\%)\end{array}$ & 39.55 & 52.37 & 8.607 \\
\hline 4. & $\begin{array}{l}\text { Fixed Carbon } \\
(\%)\end{array}$ & 36.24 & 28.08 & 32.32 \\
\hline 5. & $\begin{array}{l}\text { Hydrogen } \\
\text { content }(\%)\end{array}$ & 4.160575 & 4.44485 & 1.926813 \\
\hline 6. & $\begin{array}{l}\text { Nitrogen } \\
\text { content }(\%)\end{array}$ & 1.11698 & 1.061 & 0.75617 \\
\hline 7. & $\begin{array}{l}\text { Carbon } \\
\text { content }(\%)\end{array}$ & 59.55672 & 62.18 & 33.43611 \\
\hline 8. & $\begin{array}{l}\text { Oxygen } \\
\text { content }(\%)\end{array}$ & 8.30284 & 10.26863 & 1.967724 \\
\hline 9. & $\begin{array}{l}\text { Sulfur content } \\
(\%)\end{array}$ & 0.531 & 0.581 & 0.807 \\
\hline 10. & $\begin{array}{l}\text { Others } \\
\text { content }(\%)\end{array}$ & 2.11989 & 1.91452 & 2.03318 \\
\hline 11. & $\begin{array}{l}\text { Calorific } \\
\text { Value } \\
(\mathrm{Btu} / \mathrm{lb})\end{array}$ & 10393.25 & 10810.83 & 5685.33 \\
\hline
\end{tabular}

\subsection{Measuring of Sulfur Content from Different Myanmar Coals}

To study the effect of temperature on sulfur removal from coal, the samples were leached for 1 hour at $65{ }^{\circ} \mathrm{C}, 75^{\circ} \mathrm{C}, 85$

${ }^{\circ} \mathrm{C}$ and $95^{\circ} \mathrm{C}$. The change of the percentage of removed sulfur at different reactant temperatures is shown in (Figure 4).

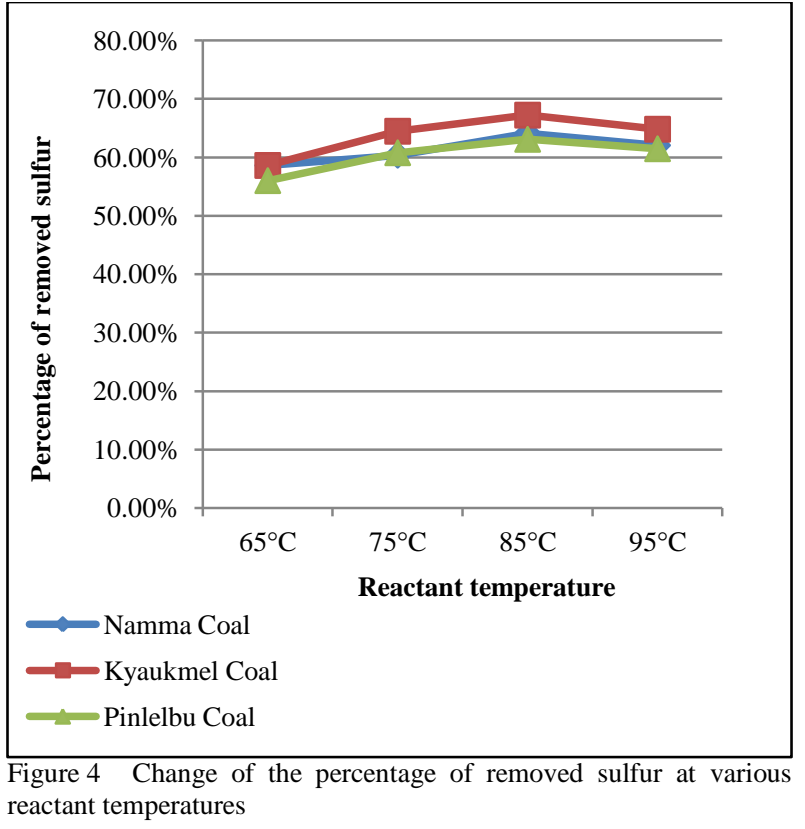

In (Figure 4), the best conditions for desulfurization of different coals were obtained at various reactant temperatures with acceptable percentage of sulfur removed. The reactant temperature of desulfurization of $85^{\circ} \mathrm{C}$ was the best condition to reduce sulfur contents for all coals. In the desulfurization of different coals the removal of sulfur content were reduced at $65{ }^{\circ} \mathrm{C}, 75{ }^{\circ} \mathrm{C}$ and $85{ }^{\circ} \mathrm{C}$, respectively, but the percentages of removed sulfur content were decreased at $95{ }^{\circ} \mathrm{C}$. Therefore, the above results show that the desulfurization process was depend on the reactant temperatures, and control-temperature was very important for removal of sulfur in coals. Generally, rate of extraction is proportion to the reactant temperature.

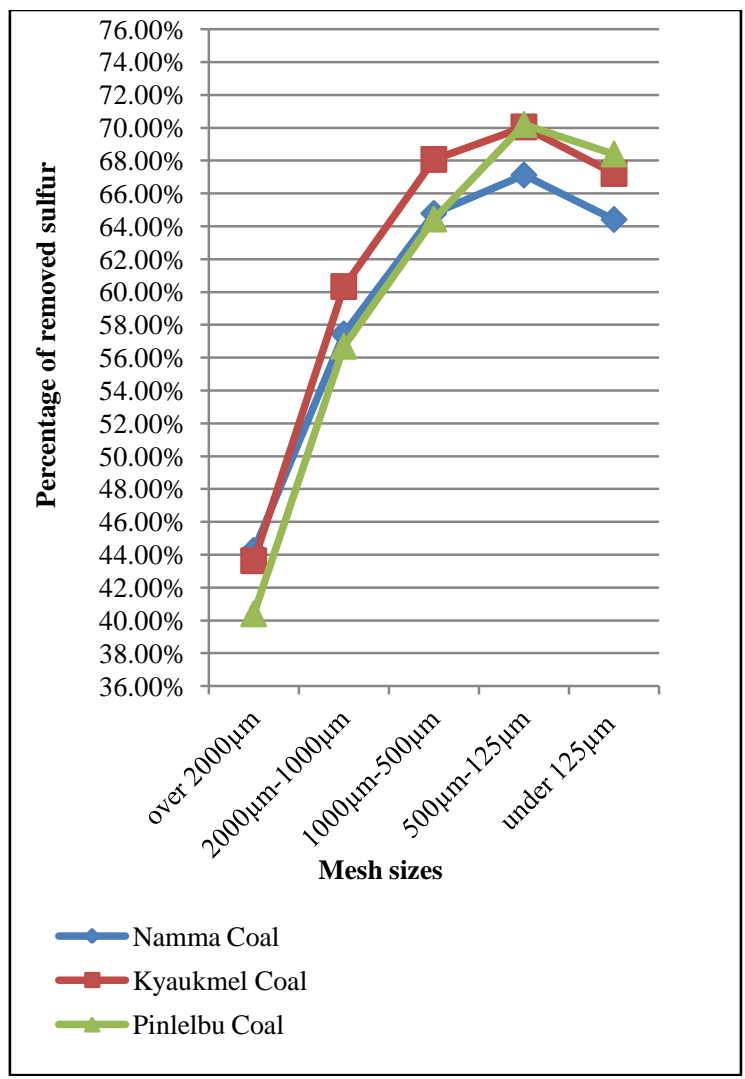

Figure 5 Change of the percentage of removed sulfur at various mesh sizes 
To study the effect of the particle size on sulfur removal from coal, samples of various particles sizes $(+2000,+1000,+500$, +125 and -125 mesh sizes) were leached at the optimum reactant temperature, $85{ }^{\circ} \mathrm{C}$ for 1 hour. (Figure 5) represents the change of the percentage of removed sulfur at different mesh sizes.

According to the (Figure 5), the results show that rate of extraction increases as mesh size decreases but after specific mesh size, the rate of leaching decreases. Particle size influences the extraction rate in a number of ways. Therefore, the percentage of removed sulfur increased from over 2000 $\mu \mathrm{m}$ to $500-125 \mu \mathrm{m}$, but the mesh size under $125 \mu \mathrm{m}$ decreased the removed sulfur content for different coals. Because the smaller the particle size, the greater is the interfacial area between the solid and liquid, and therefore the higher is the rate of transfer of material and the smaller is the distance the solute must diffuse within the solid as already indicated. On the other hand, the sulfur may not be so effectively used with a very fine material if circulation of the liquid is impeded, and the separation of the particles from the liquid and drainage of the solid residue are made more difficult. It is generally desirable that the range of particle size should be small so that each particular, the production of a large amount of fine material should be avoided as this may wedge in the interstices of the larger particles and impeded the flow of the solvent.

To study the effect of mixing reaction times on sulfur removal from coal samples of $-500+125 \mu \mathrm{m}$ (optimum size) were leached at $85{ }^{\circ} \mathrm{C}$ for $10 \mathrm{~min}, 20 \mathrm{~min}, 30 \mathrm{~min}, 40 \mathrm{~min}$ and 50 min. The change of the percentage of the removed sulfur at various reaction times is shown in (Figure 6).

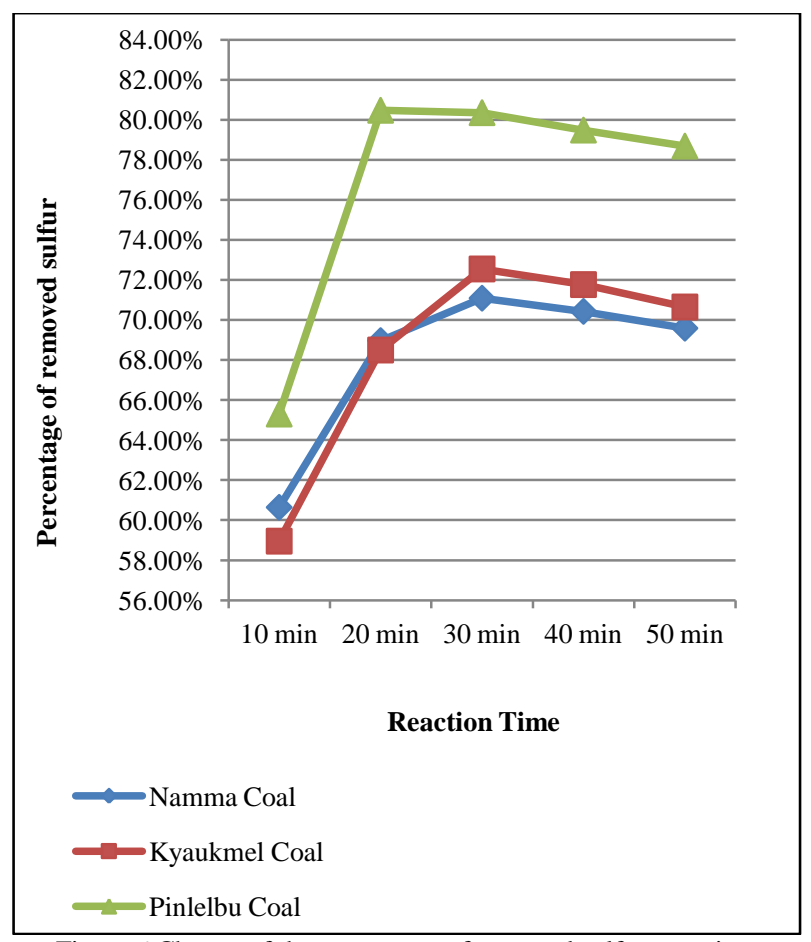

Figure 6 Change of the percentage of removed sulfur at various reaction times

In (Figure 6), it was observed that all different coals with the change of the percentage of removed sulfur at various reaction times and the maximum condition of removed sulfur contents could be obtained at the proper reaction time.

\subsection{Compositions and Calorific Values of the Different Desulfurized Coals}

The composition and calorific values of the different desulfurized coals are presented in (Table 5) by comparing with the data for before desulfurization and that of after desulfurization.

Table 5. Composition and calorific values of the different desulfurized coals

\begin{tabular}{|c|c|c|c|c|c|c|}
\hline \multirow{2}{*}{$\begin{array}{l}\text { Composi } \\
\text { tions }\end{array}$} & \multicolumn{2}{|c|}{$\begin{array}{c}\text { Namma } \\
\text { Coal }\end{array}$} & \multicolumn{2}{|c|}{$\begin{array}{c}\text { Kyaukmel } \\
\text { Coal }\end{array}$} & \multicolumn{2}{|c|}{ Pinlelbu Coal } \\
\hline & Before & After & Before & After & Before & After \\
\hline $\begin{array}{l}\text { Moisture } \\
\text { content } \\
(\mathrm{wt} ; \%)\end{array}$ & 12.90 & 2.83 & 10.06 & 3.81 & 4.213 & 4.78 \\
\hline $\begin{array}{c}\text { Ash } \\
\text { content } \\
(\mathrm{wt} ; \%)\end{array}$ & 11.31 & 47.36 & 9.49 & 57.14 & 54.86 & 59.05 \\
\hline $\begin{array}{l}\text { Volatile } \\
\text { Matter } \\
\text { (wet) } \\
\text { (wt;\%) }\end{array}$ & 39.55 & 25.31 & 52.37 & 17.55 & 8.607 & 13.49 \\
\hline $\begin{array}{l}\text { Fixed } \\
\text { Carbon } \\
(\mathrm{wt} ; \%)\end{array}$ & 36.24 & 24.5 & 28.08 & 21.5 & 32.32 & 22.68 \\
\hline $\begin{array}{c}\text { Hydroge } \\
\text { n } \\
\text { content } \\
(\mathrm{wt} ; \%)\end{array}$ & 4.16 & $\begin{array}{c}2.729 \\
981\end{array}$ & 4.44485 & $\begin{array}{c}2.119 \\
961\end{array}$ & $\begin{array}{c}1.9268 \\
13\end{array}$ & $\begin{array}{c}1.9210 \\
16\end{array}$ \\
\hline $\begin{array}{c}\text { Nitrogen } \\
\text { content } \\
(\mathrm{wt} ; \%)\end{array}$ & 1.12 & $\begin{array}{c}0.733 \\
47\end{array}$ & 1.061 & $\begin{array}{c}0.609 \\
45\end{array}$ & $\begin{array}{c}0.7561 \\
7\end{array}$ & $\begin{array}{c}0.5676 \\
9\end{array}$ \\
\hline $\begin{array}{c}\text { Carbon } \\
\text { content } \\
(\%)\end{array}$ & 59.56 & $\begin{array}{c}39.20 \\
973\end{array}$ & 62.18 & $\begin{array}{c}30.96 \\
886\end{array}$ & $\begin{array}{c}33.436 \\
11\end{array}$ & $\begin{array}{c}14.484 \\
81\end{array}$ \\
\hline $\begin{array}{l}\text { Oxygen } \\
\text { content } \\
(\mathrm{wt} ; \%)\end{array}$ & 8.30 & 7.128 & $\begin{array}{c}10.2686 \\
3\end{array}$ & $\begin{array}{c}2.089 \\
98\end{array}$ & $\begin{array}{c}1.9677 \\
2\end{array}$ & $\begin{array}{c}5.8603 \\
3\end{array}$ \\
\hline $\begin{array}{l}\text { Sulfur } \\
\text { content } \\
(\mathrm{wt} ; \%)\end{array}$ & 0.53 & $\begin{array}{c}0.153 \\
5\end{array}$ & 0.581 & $\begin{array}{c}0.159 \\
5\end{array}$ & 0.807 & 0.1575 \\
\hline $\begin{array}{l}\text { Others } \\
\text { content } \\
(\mathrm{wt} ; \%)\end{array}$ & 2.12 & $\begin{array}{c}3.586 \\
5\end{array}$ & 1.91452 & $\begin{array}{c}3.986 \\
06\end{array}$ & $\begin{array}{c}2.0331 \\
8\end{array}$ & $\begin{array}{c}3.9880 \\
6\end{array}$ \\
\hline $\begin{array}{l}\text { Calorific } \\
\text { Value } \\
(\text { Btu/lb) }\end{array}$ & $\begin{array}{c}10393 . \\
25\end{array}$ & $\begin{array}{c}6843 . \\
292\end{array}$ & $\begin{array}{c}10810.8 \\
3\end{array}$ & $\begin{array}{c}5579 . \\
365\end{array}$ & $\begin{array}{c}5685.3 \\
3\end{array}$ & $\begin{array}{c}2170.5 \\
58\end{array}$ \\
\hline
\end{tabular}

According to the (Table 5), most of the compositions from different coals were reduced from their original composition after desulfurization. And the other such as ash and other content were increased often this process. 
The calorific values for all coals were decreased from their initial value. Chemical leaching method is quite effective for removal of sulfur content from coal but this cause reduce in calorific value of as shown in (Table 6).

Table 6. Comparison of calorific values for initial coals and final coals

\begin{tabular}{|c|c|c|c|}
\hline $\begin{array}{c}\text { Raw of } \\
\text { Coal }\end{array}$ & $\begin{array}{c}\text { Calorific } \\
\text { Value } \\
\text { (Before } \\
\text { Desulfuriza- } \\
\text { tion) }\end{array}$ & $\begin{array}{c}\text { Calorific } \\
\text { Value } \\
\text { (After } \\
\text { Desulfuriza- } \\
\text { tion) }\end{array}$ & $\begin{array}{c}\text { Decreased } \\
\text { percentage }\end{array}$ \\
\hline $\begin{array}{c}\text { Namma } \\
\text { Coal }\end{array}$ & $\begin{array}{c}10393.25 \\
\text { Btu/lb }\end{array}$ & $\begin{array}{c}6843.292 \\
\text { Btu/lb }\end{array}$ & $34.16 \%$ \\
\hline $\begin{array}{c}\text { Kyaukmel } \\
\text { Coal }\end{array}$ & $\begin{array}{c}10810.83 \\
\text { Btu/lb }\end{array}$ & $\begin{array}{c}5579.365 \\
\text { Btu/lb }\end{array}$ & $48.39 \%$ \\
\hline $\begin{array}{c}\text { Pinlelbu } \\
\text { Coal }\end{array}$ & 5685.33 & 2170.558 & $61.82 \%$ \\
Btu/lb & Btu/lb & \\
\hline
\end{tabular}

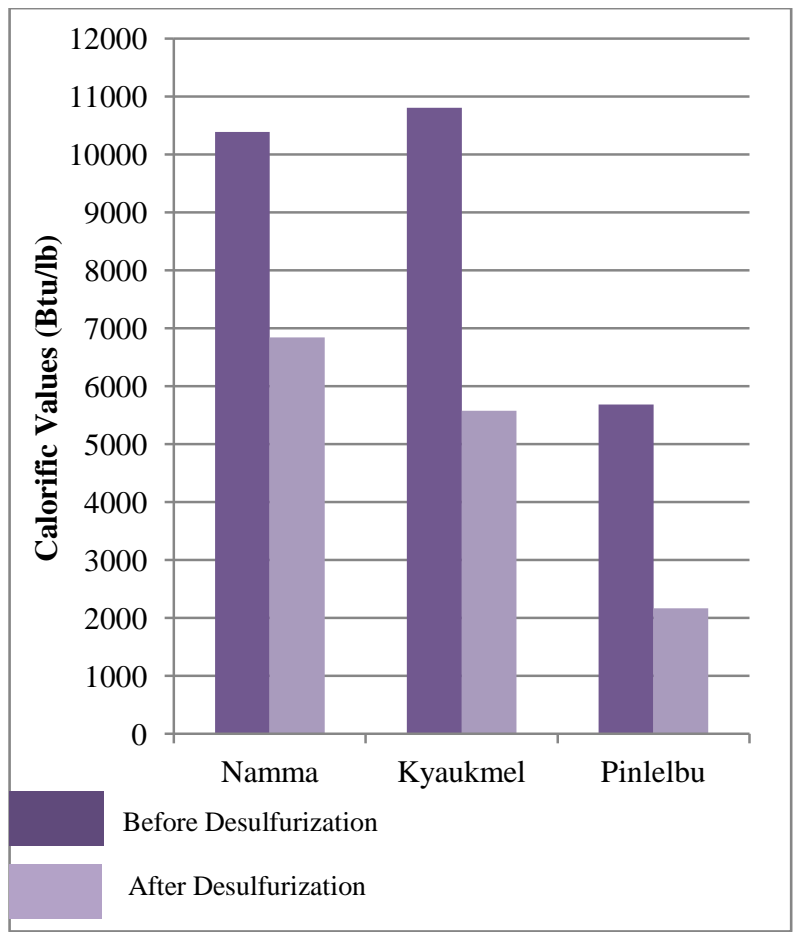

Figure 7. Changes for calorific values of different coals in before and after desulfurization

The calorific values for all coals were decreased from their initial value. Chemical leaching method is quite effective for removal of sulfur content from coal but this cause reduce in calorific value of as shown in (Figure 7).

\section{CONCLUSION}

According to the determination of characterization of different raw coals (Namma coal, Kyaukmel coal and Pinlelbu Coal), the sulfur contents of their coals were not different each other. Although the sulfur contents of each coal were not present in large amount, it was needed to remove for application and modification of coals. Therefore, sulfur removal process was carried out by using solvent leaching method. Firstly, Namma coals were used as raw material. In this method, $98 \% \mathrm{H}_{2} \mathrm{SO}_{4}$, $97 \% \mathrm{H}_{2} \mathrm{O}_{2}$ and distilled water used as a leaching solvent. Various reactant temperatures, various mesh sizes and various reaction times were done in the desulfurization process. In the same way, Kyaukmel coals and Pinlelbu coals were used to remove sulfur content from it. The rate of sulfur removal increased with increasing reactant temperature, reactant time and mesh number (decrease in particle size). Although the calorific values of the desulfurized coals were decreased, the percentages of removed sulfur were good in this process. Therefore, the obtained desulfurized coals were suitable for various applications and modifications.

Finally, in this research, the optimum conditions were got for desulfurization from different places of Myanmar. But, it can be seen that this desulfurization method is not only more costs but also occurs decreasing in heating values of coals, like other desulfurization methods. However, desulfurization of coal is absolutely necessary for the health of all human-beings and to maintain the green environment.

\section{RECOMMENDATIONS}

The following further works are recommended to do.

(1) The desulfurization process should be tested with other techniques (for example, physical techniques and biological techniques). Especially, biological methods should be tested if it will have enough time, because these methods are more effective in long period.

(2) In the leaching process, instead of sulfuric acid, other concentrate acids should be used since it is needed to wash again and again until the spent water maintains about $\mathrm{pH} 7$ after leaching because of sulfur content in sulfuric acid.

\section{ACKNOWLEDGEMENTS}

The authors wish to express their gratitude to all teachers, especially their supervisor, for guiding the knowledge, as well as invaluable experiences and other valuable kindness supports.

\section{REFERENCES}

[1] Ali Ahmed \& Naseer Ahmed, 2008. Coal Desulfurization by Solvent Leaching Method, Journal of Faculty of Engineering \& Technology.

[2] American Coal Foundation, Types of Coals, December 15, 2005. Available: http://www.types

[3] Anonymous, Coal, Wikipedia, the free encyclopedia, January 2, 2009. Available: http://www.En.Wikipedial

[4] Anonymous, Coal Analytical Methods Blackwell Scientific Press, 1984.http:/www. Coal assay.pdf

[5] Anonymous, Homeland security: U.S. Brown field, Power Engineering Volume.106, No.6, June, 2002.

[6] Bruce G. Miller, Coal Energy Systems, Elsevier, Inc., October 29, 2004.

[7] Coal_ Review.pdf February, 2003. Available: http://www. MARSTON SoutheastAsia

[8] Dr. C. Otto, March, 1969.. Report on Tests and Studies for the Production of Merallurgical Coke From Kalewa Coal, No. (1) Iron and Steel Industry, Myanmar.

[9] E.Bolat, S. Saglam and S. Piskin, 1998.. Fuel Processing Technology 57

[10] Energy.gov/education/energy lesson/coal_cct2.html, 2008 Available: http://www.fossile

[11] George Granger Brown, 1958. Unit Operations, Modern Asia Edition, John Wiley \& Sons, Inc., New York, \& Charles E. Tuttle Co., Tokyo.

[12] K. Komnitsas \& C. September, 2001. Stouraiti, Sulfur removal from Coal Beneficiation Wastes, $7^{\text {th }}$ CEST Conference, Syros, Greece.

[13] S. Mukherjee and P.C. Borthakur, 2003.Fuel Processing Technology, 
International Journal of Science and Engineering Applications

Volume 8-Issue 02,68-74, 2019, ISSN:-2319-7560

[14] Warren L. McCabe: 1993. Unit Operations of Chemical Engineering, $5^{\text {th }}$ Edition, McGraw-Hill, Inc., New York.. 